\title{
Seed rain in a restoration site and in an adjacent remnant of Seasonal Atlantic Forest
}

\author{
Chuva de sementes em reflorestamento e em remanescente adjacente de \\ Floresta Estacional Atlântica
}

\section{Vanessa França VindicaI, Larissa Rafaela Bargoena ${ }^{\mathrm{II}}$, Pamela Cristina Santana ${ }^{\mathrm{III}}$, José Antonio Pimenta ${ }^{\mathrm{IV}}$, Alba Lucia Cavalheiro ${ }^{\mathrm{IV}}$, José Marcelo Domingues Torezan ${ }^{\mathrm{IV}}$, Edmilson Bianchini ${ }^{\mathrm{IV}}$}

\begin{abstract}
Ecological succession depends on the seed rain. While the simple arrival of seeds is not assurance of establishment, knowing the seed rain is the first approach to assessing the succession process in sites undergoing forest restoration. For this reason, we sampled the seed rain in a restoration site and in an adjacent seasonal semi-deciduous forest remnant in southern Brazil, in order to describe the process. In each area, 18 seed traps $\left(1 \mathrm{~m}^{2}\right)$ were allocated and visited monthly for two years. All seeds trapped were identified, counted and classified by life form, ecological group and dispersal syndrome. The forest remnant presented higher species richness and abundance of propagules than the restoration site. The composition of species also differed between areas. The seed rain of both areas presented a higher proportion of tree and shade-intolerant species. Several non-planted species, possibly dispersed from forest remnant, were recorded in the restoration site. Analysis of the results suggests that the seed rain is not a constraint to succession in the restoration site. However, the site should be monitored in the long term to assess the establishment, and not only the arrival of seeds of late successional species.
\end{abstract}

Keywords: Dispersal; Propagules; Seasonality; Ecological succession

\section{Resumo}

A sucessão ecológica depende da chuva de sementes. Embora a simples chegada de sementes não garanta o estabelecimento, conhecer a chuva de sementes é o primeiro passo para avaliar o processo sucessional em sítios sob restauração florestal. Por essa razão, foi amostrada a chuva de sementes em reflorestamento e em remanescente de floresta estacional semidecidual no sul do Brasil, a fim de descrever o processo. Em cada área, 18 armadilhas de sementes $\left(1 \mathrm{~m}^{2}\right)$ foram alocadas e visitadas, mensalmente, por dois anos. Todas as sementes amostradas foram identificadas, contadas e classificadas quanto à forma de vida, grupo ecológico e síndrome de dispersão. O remanescente florestal apresentou maior riqueza de espécies e abundância de propágulos que o reflorestamento. A composição de espécies também diferiu entre as áreas. A chuva de sementes, de ambas as áreas, apresentou maior proporção de árvores e de espécies intolerantes à sombra. Várias espécies não plantadas no reflorestamento, possivelmente dispersadas a partir do remanescente florestal, foram registradas no sítio em restauração. A análise dos resultados sugere que a chuva de semente não é um impedimento ao processo sucessional no reflorestamento. Entretanto, o sítio deve ser monitorado por mais tempo a fim de avaliar o estabelecimento, e não somente a chegada de sementes de espécies sucessionais tardias.

Palavras-chave: Dispersão; Propágulos; Sazonalidade; Sucessão ecológica

Bióloga, Ma., Pesquisadora Autônoma, Rua Barão de Mauá, 253, apto 2, Jardim Imperial, CEP 39100-000, Diamantina (MG), Brasil.v.francavindica@ yahoo.com.br (ORCID: 0000-0002-2633-2658)

Bióloga, Analista, Gerência de Saúde, Segurança, Meio Ambiente e Riscos, Metais Básicos Atlântico Sul, Vale S.A., Rua Grajaú, 63, CEP 68516-000, Parauapebas (PA), Brasil. larissa.bargoena@vale.com (ORCID: 0000-0002-4101-7787)

III Bióloga, Doutoranda, Departamento de Ecologia, Instituto de Biociências, Universidade de São Paulo, Rua do Matão, 277, travessa 14, Butantã, CEP 05508-090, São Paulo (SP), Brasil. pcsantana@ib.usp.br (ORCID: 0000-0002-7517-6671)

IV Biólogos, Dr/Dra., Professor Associado/Pesquisadora do Departamento de Biologia Animal e Vegetal, Centro de Ciências Biológicas, Universidade Estadual de Londrina, Campus Universitário, Caixa Postal 10011, CEP 86057-970, Londrina (PR), Brasil. pimenta@uel.br (ORCID: 0000-0001-74868855) / alba@uel.br (ORCID: 0000-0002-5302-9259) / torezan@uel.br (ORCID: 0000-0001-7962-1499) / bianchi@uel.br (ORCID: 0000-0002-4764-3324) 


\section{Introduction}

In fragmented and degraded tropical landscapes, many studies have suggested that seed availability is a major limiting factor in vegetation recovery (e.g. JESUS et al., 2012), because most plants that will establish in disturbed areas are derived from seeds coming from the site neighborhood. Therefore, this process will contribute to the recruitment of new plants and to the species turnover, allowing changes in community composition and structure (JESUS et al., 2012).

In most degraded sites, local seed sources of tree native species are scarce and the soil seed bank is depleted (GUARIGUATA; OSTERTAG, 2001). Thus, secondary succession will depend on the seed rain, which includes seeds coming from nearby sites (MARTINEZ-RAMOS; SOTOCASTRO, 1993; REID; HOLL; ZAHAWI, 2015). In early succession and in active restoration sites, the locally produced propagules will be responsible for the self-regeneration of the population and maintenance of genetic composition, while propagules arriving from the external sources will increase local diversity and genetic variability (MARTINEZ-RAMOS; SOTO-CASTRO, 1993).

The proximity of the forest remnants is a decisive factor in the restoration of degraded sites, because the forest remnants act as important sources of diaspores (ENDRESS; CHINEA, 2001; PEREIRA; OLIVEIRA; TOREZAN, 2013). This proximity facilitates the passage of seed-dispersing animals and the arrival of new plant species (JESUS et al., 2012). Zamora and Montagnini (2007) observed that the restoration sites located adjacent to a secondary forest had greater seed abundance and species richness of seeds than sites surrounded by the other restoration sites and not by the forest. These authors also recorded that most observations of animals were made next to the secondary forest.

Parallel to the increase of sites being restored, there was an increase in the search for methods of restoration monitoring, allowing predictive analyses and giving support for adaptive management (SUGANUMA; DURIGAN, 2015). The composition of seed rain can be used as an indicator of the future development of a restoration site, because it was expected to increase the species richness, mainly of shade-tolerant and animal-dispersed species (JESUS et al., 2012), whenever the distance from sources of propagules is not a limiting factor.

By sampling the seed rain in a 10-year old restoration site adjacent to an Atlantic forest fragment, we aimed to describe the process and answer the following questions: (1) Do richness and composition species of propagules differ between reforestation and forest remnant? (2) Does seed rain change between years? (3) Are there qualitative and quantitative changes in the seed rain due to the climatic seasonality? (4) Do seed rain species' attributes (life form, ecological group and dispersal syndrome) differ between reforestation and forest remnant?

\section{Material and methods}

\section{Study area}

This study was carried out in a 108 ha seasonal semi-deciduous forest remnant (hereafter SF) within the Atlantic Forest biome, and in an adjacent 10-year old restoration site

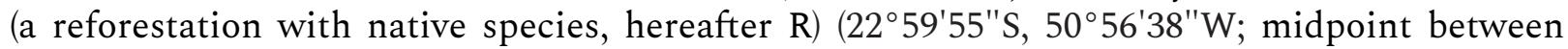
the two adjacent sites), located in Rancho Alegre municipality, northern Paraná state, southern Brazil (Figure 1). Past disturbance at the SF, which included selective logging (in the 1970's), firewood and palm heart exploration, have resulted in discontinuity in the canopy and liana overpopulation. $\mathrm{R}$ is an 11.8 ha stretch of reforestation with approximately $40 \%$ of its perimeter alongside with the SF. Seedling planting was done with a $3 \times 2 \mathrm{~m}$ spacing, without fertilization. Forty native tree species were planted with high density of shade-intolerant species, such as 
Guazuma ulmifolia Lam., Schinus terebinthifolius Raddi, Heliocarpus popayanensis Kunth., Cecropia pachystachya Trécul and Trema micrantha (L.) Blume., in order to control the invasion of grasses by shading (CAVALHEIRO; TOREZAN; FADELLI, 2002). Mechanized grass control was done until the second year after planting. Both areas are surrounded by a predominantly agricultural matrix, and they have no connection with other forest remnants.

According to Köppen's classification, the regional climate is Cfa - humid subtropical, with hot and humid summers (ALVARES et al., 2013). Annual rainfall is about $1200-1400 \mathrm{~mm}$ with the cooler and drier trimester from June to August, when the mean monthly rainfall stays between 175-200 mm, while in the hotter and rainier trimester (from December to February), the mean monthly rainfall stays between $500-600 \mathrm{~mm}$. The mean monthly temperature is $22^{\circ} \mathrm{C}$. Regional soil was sourced from basaltic rock and is classified as Eutropherric Red Latosols.

\section{Data collection}

To evaluate the seed rain, we placed 36 seed traps, 18 at the SF and 18 at the R site. In each area, the seed traps were spaced at least $10 \mathrm{~m}$ from each other, in two transects departing from a track and perpendicular to it, going in opposite directions (Figure 1). The seed traps were installed $70 \mathrm{~cm}$ from the ground to prevent the collection of herbaceous species seeds and to reduce the chances of seed predation by terrestrial animals. They were made of wood and nylon mesh $(1-\mathrm{mm})$, with the inner area of $1 \mathrm{~m}^{2}$ and $15 \mathrm{~cm}$ deep.

Figure 1 - Location of seasonal semi-deciduous forest remnant (SF) and adjacent reforestation (R) at Fazenda Congonhas, Rancho Alegre municipality, northern Paraná state, southern Brazil. The yellow lines indicate the transects where the seed traps were installed

Figura 1 - Localização do remanescente de floresta estacional semidecidual (SF) e reflorestamento adjacente (R) na Fazenda Congonhas, Rancho Alegre, norte do Paraná, sul do Brasil. As linhas amarelas indicam os transectos onde as armadilhas de sementes foram instaladas

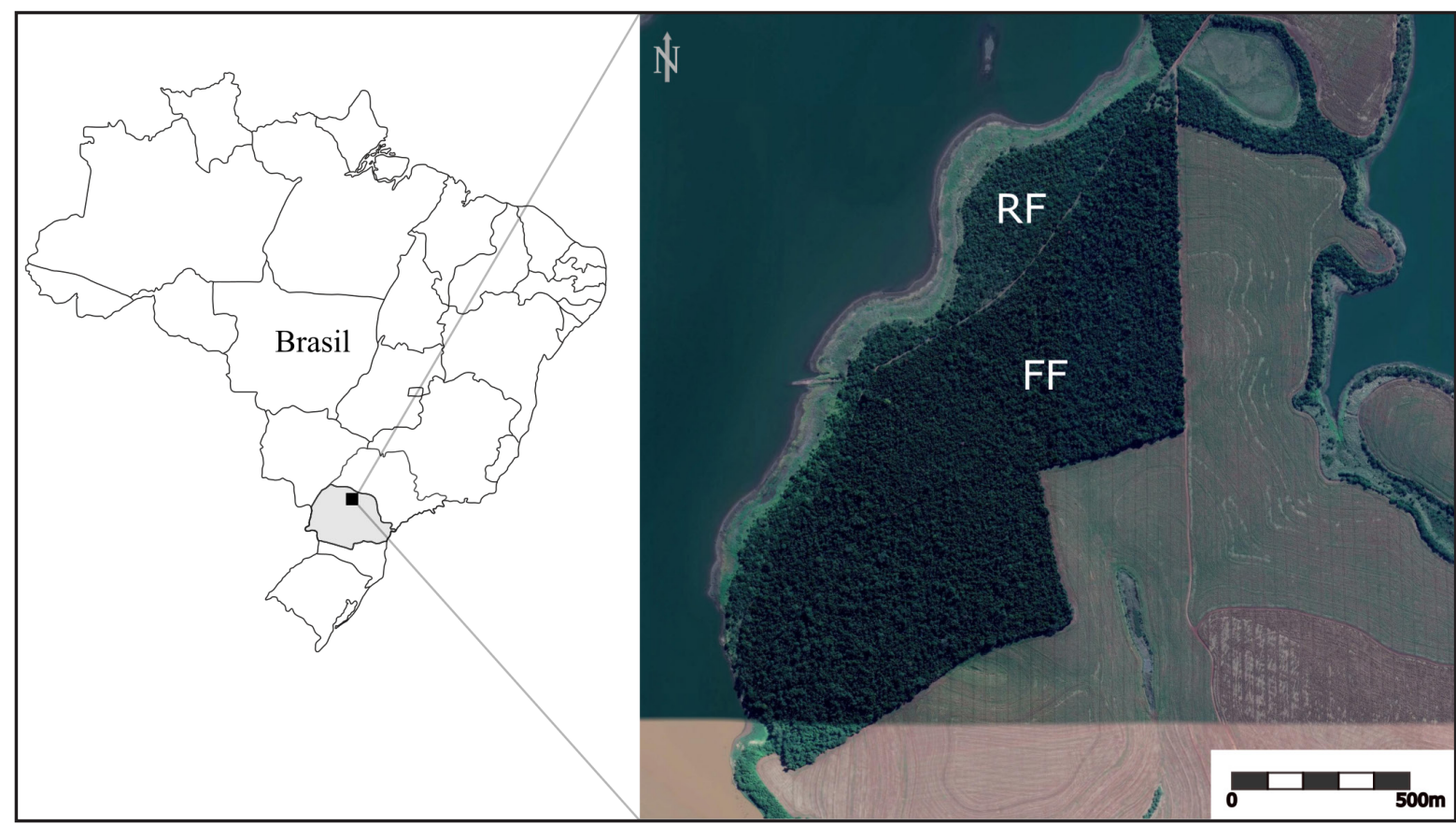

Source: Authors (2020) 
Seed traps were emptied monthly throughout the two years of sampling (November 2008 to October 2010). The collected materials were brought to the laboratory, dried if necessary and the viable diaspores (without signs of predation or decay) were separated from the other components of the litter (twigs, leaves, flowers, animals, etc.) and counted.

Diaspores were identified to the species level whenever possible with specialist aid, and by comparison with a reference collection, as well as by consulting the FUEL herbarium of the State University of Londrina. Species were grouped in families according to APG IV (2016) and the names and authorities are in accord with the Checklist of the Brazilian Flora (FLORA DO BRASIL, 2019). The unidentified seeds were assigned to morphospecies categories. The term "species" as utilized hereafter refers to all fully identified species, as well as the morphospecies.

Species were classified according to life form (tree, shrub, liana, and herb), ecological group (shade-tolerant or shade-intolerant) and dispersal syndrome (anemochory, zoochory, autochory). Ecological group and dispersal syndrome were assigned to each species based on the morphology of the diaspores, the literature (e.g., SILVA; SOARES-SILVA, 2000; CAVALHEIRO; TOREZAN; FADELLI, 2002) and specialist consultation. However, it should be emphasized that several species were not identified and, therefore, these results should be viewed with caution.

\section{Data analysis}

In each month, data from all seed traps in each sample area were grouped together for all analyses involving number of species and number of seeds. We generated rarefaction curves for each area, and the species richness was evaluated by Bootstrap estimator, using the EstimateS 9.1.0 software (COLWELL, 2013), after 100 randomizations, with 95\% confidence intervals. To assess the composition of species, indirect sorting was carried out by Non-Metric Multidimensional Scaling (NMDS) using two axes for analysis. We used the quantitative data and Bray-Curtis similarity measure. After that, we used the Permutational Multivariate Analysis of Variance (PERMANOVA) to test the influence of different sites and seasons in the species composition. Both analyses were performed in $\mathrm{R}$ software 3.0.2 with the Vegan 2.2-1 package ( $\mathrm{R}$ CORE TEAM, 2014).

To compare the seasonality in the species richness, propagules abundance, and dispersal syndrome abundance in the seed rain, two seasons was defined: the rainy season (from October to March) and the dry season, (from April to September). We used the Kruskal-Wallis and MannWhitney tests to compare the abundance of seeds and species richness (monthly data) between areas and season. Both analyses were performed in Past software (HAMMER; HARPER; RYAN, 2001).

\section{Results and discussion}

We recorded 120 different taxa of seeds in the SF and R, of which, 55 were identified to the species level, 13 to the genus level, 20 to the family level and 32 taxa could not be identified (Table 1). The most representative families in species richness were Bignoniaceae (15), Fabaceae (11), Sapindaceae (7) and Meliaceae (6). In the SF and R, we recorded 101 and 63 species, respectively, and both areas showed $86 \%$ of estimated richness by Bootstrap (Figure 2). Of the 63 species sampled in the $\mathrm{R}$ seed rain, 14 species were used in planting. We recorded 57 species exclusive to the SF, 19 to the R and 44 species were sampled in both areas (Table 1). Of the species sampled only in R, six also occur in the SF, but were not sampled in its seed rain. If we considered only identified species, at least until the genus level (68), 29 species were common in both areas, being that only 10 species were planted in $\mathrm{R}$ (Table 1). Therefore, at least $33 \%$ of identified species were probably dispersal from SF. Of the 100 species sampled in a woody species floristic survey in the SF (T. P. FERRACIN, unpublished data), 64 tree and shrubs species were not sampled in the SF seed rain. Among them, two species were sampled in the $\mathrm{R}$ (Aloysia virgata and Eugenia pyriformis). 
Species richness in the first year $(\mathrm{SF}=54, \mathrm{R}=47)$ was lower than in the second year (SF $=83, \mathrm{R}=51$ ), in both areas. In a seasonal semi-deciduous forest (SF) remnant, 54 species were recorded in a year of sampling (GROMBONE-GUARATINI; RODRIGUES, 2002), similar to first year of this study. In contrast, in a biennial survey of the seed rain in the SF secondary remnant (CAMPOS et al., 2009) and a riparian forest remnant (ARAUJO et al., 2004), 43 and 50 species were sampled, respectively. These results indicate that both SF and $\mathrm{R}$ showed considerable richness, in spite of human disturbance.

Figure 2 - Cumulative curve of propagules species in the seed rain of a reforestation site $(\mathbf{R})$ and an adjacent seasonal semi-deciduous forest remnant (SF) at the northern Paraná, southern Brazil, with $\mathbf{9 5 \%}$ confidence intervals (errors bars)

Figura 2 - Curva cumulativa de espécies de propágulos na chuva de sementes de um reflorestamento $(\mathrm{R})$ e de remanescente de floresta estacional semidecidual adjacente (SF) no norte do Paraná, sul do Brasil, com intervalo de confiança de 95\% (barras de erro)

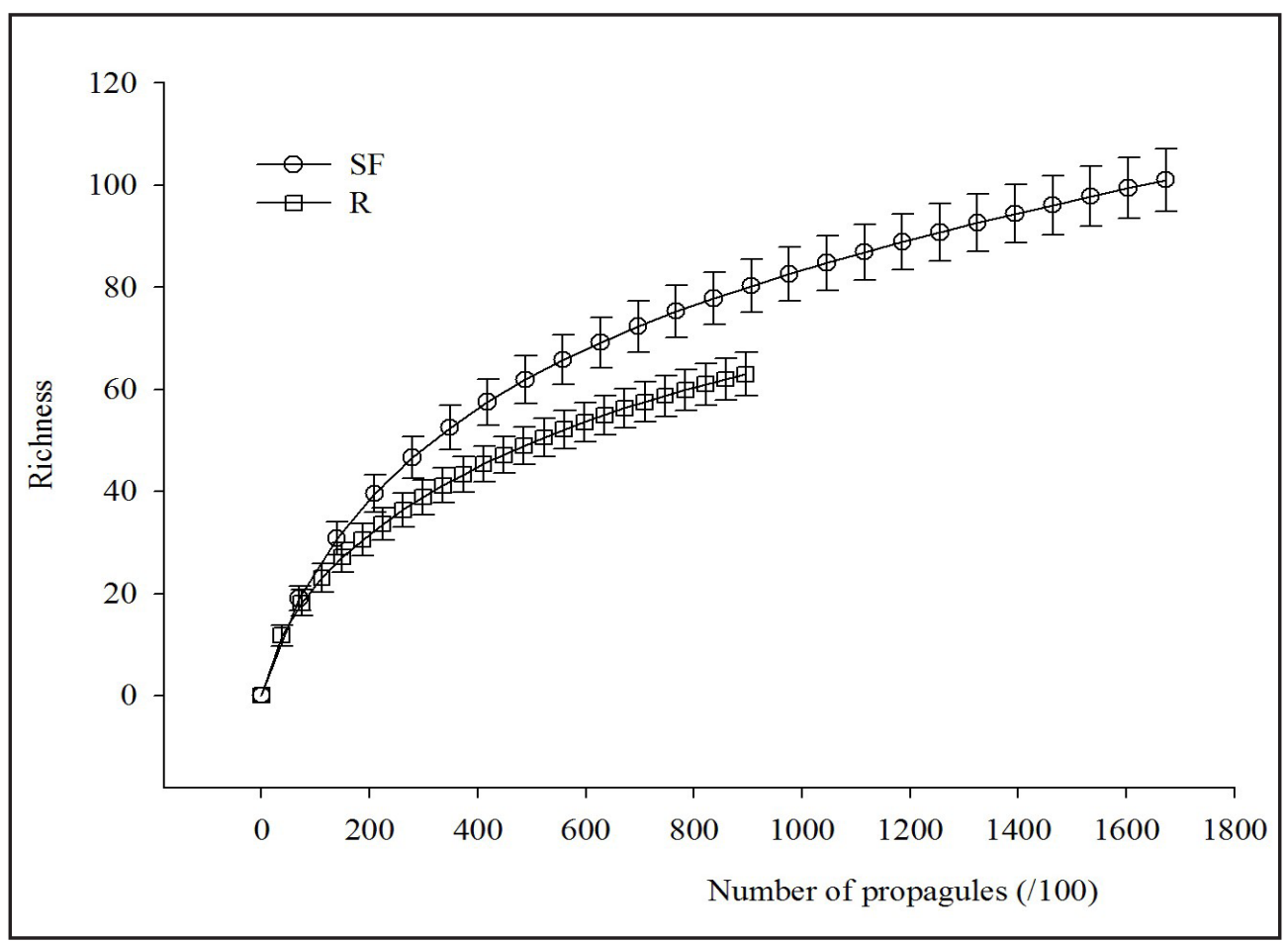

Source: Authors (2020)

We sampled 167,300 propagules in the SF, being $72 \%$ in the first year, mainly because of Ficus eximia $(>100,000$ propagules). In the second year, the species that mostly contributed were Ficus eximia $(>18,000)$ and Casearia gossypiosperma $(>12,000)$. Of the 89,625 propagules of the $\mathrm{R}$, $51 \%$ were sampled in the first year with more contribution of Heliocarpus popayanensis $(>13,000)$, Schinus terebinthifolius $(>10,000$ propagules) and Ficus eximia $(>8,000)$. In the second year, the most predominant species were Schinus terebinthifolius $(>11,000)$ and Heliocarpus popayanensis $(>9,000)$. In general, Schinus terebinthifolius, Heliocarpus popayanensis, Ficus eximia, Cecropia pachystachya, Trema micrantha and Bastardiopsis densiflora were the species that most contributed to the seed rain of the reforestation. These species, except Ficus eximia, were planted in the R (Table 1) and are often used in restoration projects, because they are pioneer species and fast-growing (CAVALHEIRO; TOREZAN; FADELLI, 2002). 
Table 1 - List of species per family sampled in the seed rain in the reforestation $(R)$ and in the adjacent seasonal semi-deciduous forest remnant $(F)$ in the northern Paraná, southern

\section{Brazil, from November/2008 to October/2010}

Tabela 1 - Lista de espécies, por família, amostradas na chuva de sementes em reflorestamento (R) e em remanescente de floresta estacional semidecidual adjacente (F) no norte do Paraná, sul do Brasil, de novembro/2008 a outubro/2010

\begin{tabular}{|c|c|c|c|c|c|}
\hline Families/Species & $\mathbf{F}$ & $\mathbf{R}$ & $\mathbf{L F}$ & EG & DS \\
\hline \multicolumn{6}{|l|}{ Anacardiaceae } \\
\hline Schinus terebinthifolius Raddi* & $\mathrm{X}$ & $\mathrm{X}$ & $\mathrm{T}$ & SI & $\mathrm{Z}$ \\
\hline \multicolumn{6}{|l|}{ Apocynaceae } \\
\hline Aspidosperma polyneuron Müll. Arg. & $\mathrm{X}$ & & $\mathrm{T}$ & ST & A \\
\hline Tabernaemontana catharinensis A. DC.* & & $\mathrm{X}$ & $\mathrm{T}$ & SI & $\mathrm{Z}$ \\
\hline Tabernaemontana hystrix Steud. & & $\mathrm{X}$ & $\mathrm{T}$ & SI & $\mathrm{Z}$ \\
\hline \multicolumn{6}{|l|}{ Arecaceae } \\
\hline Euterpe edulis Mart. & $\mathrm{X}$ & & $\mathrm{T}$ & ST & $\mathrm{Z}$ \\
\hline Syagrus romanzoffiana (Cham.) Glassman & $\mathrm{X}$ & & $\mathrm{T}$ & SI & $\mathrm{Z}$ \\
\hline \multicolumn{6}{|l|}{ Asteraceae } \\
\hline Asteraceae 3 & & $\mathrm{X}$ & - & - & A \\
\hline Vernonanthura discolor (Spreng.) H. Rob. & $\mathrm{X}$ & $\mathrm{X}$ & $\mathrm{T}$ & SI & A \\
\hline \multicolumn{6}{|l|}{ Bignoniaceae } \\
\hline Bignoniaceae 1 & $\mathrm{X}$ & & - & - & A \\
\hline Bignoniaceae 3 & $\mathrm{X}$ & $\mathrm{X}$ & - & - & A \\
\hline Bignoniaceae 7 & $\mathrm{X}$ & & - & - & A \\
\hline Bignoniaceae 8 & $\mathrm{X}$ & & - & - & A \\
\hline Bignoniaceae 9 & $\mathrm{X}$ & & - & - & A \\
\hline Bignoniaceae 10 & $\mathrm{X}$ & $\mathrm{X}$ & - & - & A \\
\hline Bignoniaceae 12 & $\mathrm{X}$ & & - & - & A \\
\hline Bignoniaceae 13 & $\mathrm{X}$ & & - & - & A \\
\hline Bignoniaceae 14 & $\mathrm{X}$ & & - & - & A \\
\hline Bignoniaceae 18 & $\mathrm{X}$ & & - & - & A \\
\hline Bignoniaceae 21 & & $\mathrm{X}$ & - & - & - \\
\hline Bignoniaceae 22 & & $\mathrm{X}$ & - & - & - \\
\hline Bignoniaceae 23 & $\mathrm{X}$ & $\mathrm{X}$ & - & - & A \\
\hline Handroanthus impetiginosus (Mart. ex DC.) Mattos & $\mathrm{X}$ & & $\mathrm{T}$ & ST & A \\
\hline Tabebuia sp. & $\mathrm{X}$ & & $\mathrm{T}$ & - & A \\
\hline \multicolumn{6}{|l|}{ Boraginaceae } \\
\hline Cordia americana (L.) Gottschling \& J. S. Mill. & $\mathrm{X}$ & & $\mathrm{T}$ & SI & A \\
\hline
\end{tabular}


Tabela 1 - Continuação ...

Table 1 - Continuation ...

\begin{tabular}{|c|c|c|c|c|c|}
\hline Families/Species & $\mathbf{F}$ & $\mathbf{R}$ & $\mathbf{L F}$ & EG & DS \\
\hline \multicolumn{6}{|l|}{ Cannabaceae } \\
\hline Trema micranta $\left(\right.$ L.) Blume ${ }^{*}$ & $\mathrm{X}$ & $\mathrm{X}$ & $\mathrm{T}$ & SI & $\mathrm{Z}$ \\
\hline \multicolumn{6}{|l|}{ Euphorbiaceae } \\
\hline Alchornea triplinervia (Spreng.) Müll. Arg. & $\mathrm{x}$ & $\mathrm{X}$ & $\mathrm{T}$ & SI & $\mathrm{Z}$ \\
\hline Croton floribundus Spreng.* & $\mathrm{X}$ & $\mathrm{X}$ & $\mathrm{T}$ & SI & $\mathrm{Au}$ \\
\hline Croton urucurana Baill. & $\mathrm{X}$ & $\mathrm{X}$ & $\mathrm{T}$ & SI & $\mathrm{Au}$ \\
\hline Tetrorchidium rubrivenium Poepp. & $\mathrm{x}$ & & $\mathrm{T}$ & SI & $\mathrm{Z}$ \\
\hline \multicolumn{6}{|l|}{ Fabaceae } \\
\hline Acacia polyphylla DC. & $\mathrm{X}$ & & $\mathrm{T}$ & SI & $\mathrm{Au}$ \\
\hline Albizia niopioides (Benth.) Burkart.* & $\mathrm{X}$ & & $\mathrm{T}$ & SI & $\mathrm{Au}$ \\
\hline Centrolobium tomentosum Guillemin ex Benth. & $\mathrm{X}$ & & $\mathrm{T}$ & SI & A \\
\hline Enterolobium contortisiliquum (Vell.) Morong* & $\mathrm{X}$ & & $\mathrm{T}$ & SI & $\mathrm{Au}$ \\
\hline Fabaceae 1 & $\mathrm{x}$ & & - & - & $\mathrm{Au}$ \\
\hline Fabaceae 3 & $\mathrm{X}$ & & - & - & $\mathrm{Au}$ \\
\hline Fabaceae 5 & $\mathrm{X}$ & & - & - & $\mathrm{Au}$ \\
\hline Lonchocarpus muehlbergianus Hassl. & $\mathrm{X}$ & $\mathrm{X}$ & $\mathrm{T}$ & SI & A \\
\hline Mucuna pruriens var. utilis (Wall. ex Wight) Baker ex Burck $\S$ & $\mathrm{X}$ & $\mathrm{X}$ & $\mathrm{L}$ & - & $\mathrm{Au}$ \\
\hline Parapiptadenia rigida (Benth.) Brenan & $\mathrm{x}$ & $\mathrm{X}$ & $\mathrm{T}$ & SI & $\mathrm{Au}$ \\
\hline Pterogyne nitens Tul.* & $\mathrm{X}$ & $\mathrm{X}$ & $\mathrm{T}$ & SI & A \\
\hline \multicolumn{6}{|l|}{ Lamiaceae } \\
\hline Aegiphila sellowiana Cham. ${ }^{*}$ & $\mathrm{X}$ & $\mathrm{X}$ & $\mathrm{T}$ & SI & $\mathrm{Z}$ \\
\hline \multicolumn{6}{|l|}{ Lauraceae } \\
\hline Ocotea elegans Mez & $\mathrm{X}$ & & $\mathrm{T}$ & ST & $\mathrm{Z}$ \\
\hline Ocotea velutina (Nees) Rohwer & $\mathrm{X}$ & & $\mathrm{T}$ & ST & $\mathrm{Z}$ \\
\hline \multicolumn{6}{|l|}{ Malpighiaceae } \\
\hline Malpighiaceae 1 & $\mathrm{X}$ & $\mathrm{X}$ & - & - & A \\
\hline Malpighiaceae 2 & $\mathrm{X}$ & & - & - & A \\
\hline \multicolumn{6}{|l|}{ Malvaceae } \\
\hline Ceiba speciosa (A. St.-Hil.) Ravenna* & & $\mathrm{X}$ & $\mathrm{T}$ & SI & A \\
\hline Bastardiopsis densiflora (Hook. \& Arn.) Hassl. & $\mathrm{X}$ & $\mathrm{X}$ & $\mathrm{T}$ & SI & A \\
\hline Guazuma ulmifolia Lam.* & & $\mathrm{X}$ & $\mathrm{T}$ & SI & $\mathrm{Au}$ \\
\hline Heliocarpus popayanensis Kunth ${ }^{*}$ & $\mathrm{x}$ & $\mathrm{x}$ & $\mathrm{T}$ & SI & A \\
\hline \multicolumn{6}{|l|}{ Melastomataceae } \\
\hline Miconia sp. & $\mathrm{X}$ & $\mathrm{X}$ & - & - & - \\
\hline
\end{tabular}

Ci. Fl., Santa Maria, v. 30, n. 4, p. 1230-1244, out./dez. 2020 
Tabela 1 - Continuação ...

Table 1 - Continuation ...

\begin{tabular}{|c|c|c|c|c|c|}
\hline Families/Species & $\mathbf{F}$ & $\mathbf{R}$ & $\mathbf{L F}$ & EG & DS \\
\hline \multicolumn{6}{|l|}{ Meliaceae } \\
\hline Cedrela odorata $\mathrm{L}$. & $\mathrm{x}$ & & $\mathrm{T}$ & ST & A \\
\hline Guarea kunthiana A. Juss. & $\mathrm{X}$ & & $\mathrm{T}$ & ST & $\mathrm{Z}$ \\
\hline Trichilia elegans A. Juss. & $\mathrm{x}$ & $\mathrm{X}$ & $\mathrm{T}$ & ST & $\mathrm{Z}$ \\
\hline Trichilia pallens C. DC. & $\mathrm{X}$ & & $\mathrm{T}$ & ST & $\mathrm{Z}$ \\
\hline Trichilia sp & & $\mathrm{X}$ & - & - & $\mathrm{Z}$ \\
\hline Trichilia sp2 & $\mathrm{X}$ & & - & - & $\mathrm{Z}$ \\
\hline \multicolumn{6}{|l|}{ Moraceae } \\
\hline Ficus sp1 & $\mathrm{X}$ & & $\mathrm{T}$ & SI & $\mathrm{Z}$ \\
\hline Ficus sp2 & $\mathrm{X}$ & $\mathrm{X}$ & $\mathrm{T}$ & SI & $\mathrm{Z}$ \\
\hline Ficus eximia Schott & $\mathrm{X}$ & $\mathrm{X}$ & $\mathrm{T}$ & SI & $\mathrm{Z}$ \\
\hline Maclura tinctoria (L.) D. Don ex Steud. & $\mathrm{X}$ & $\mathrm{X}$ & $\mathrm{T}$ & SI & $\mathrm{Z}$ \\
\hline \multicolumn{6}{|l|}{ Myrtaceae } \\
\hline Psidium guajava $\mathrm{L}$. & $\mathrm{X}$ & $\mathrm{X}$ & $\mathrm{T}$ & SI & $\mathrm{Z}$ \\
\hline Eucalyptus grandis W. Hill ex Maiden $§$ & & $\mathrm{x}$ & $\mathrm{T}$ & SI & A \\
\hline Eugenia pyriformis Cambess. & & $\mathrm{X}$ & $\mathrm{T}$ & ST & $\mathrm{Z}$ \\
\hline \multicolumn{6}{|l|}{ Nyctaginaceae } \\
\hline Bougainvillea spectabilis Willd. & $\mathrm{x}$ & $\mathrm{X}$ & $\mathrm{T}$ & SI & A \\
\hline Pisonia ambigua Heimrl & $\mathrm{X}$ & $\mathrm{X}$ & $\mathrm{T}$ & ST & $\mathrm{Z}$ \\
\hline \multicolumn{6}{|l|}{ Phytolaccaceae } \\
\hline Phytolacca dioica $\mathrm{L} .{ }^{*}$ & & $\mathrm{x}$ & $\mathrm{T}$ & SI & $\mathrm{z}$ \\
\hline \multicolumn{6}{|l|}{ Poaceae } \\
\hline Megathyrsus maximus (Jacq.) B. K. Simon\& S.W.L. Jacobs § & & $\mathrm{X}$ & $\mathrm{H}$ & SI & A \\
\hline \multicolumn{6}{|l|}{ Rhamnaceae } \\
\hline Colubrina gladulosa Perkins* & $\mathrm{X}$ & $\mathrm{X}$ & $\mathrm{T}$ & SI & $\mathrm{Au}$ \\
\hline Gouania ulmifolia Hook. \& Arn. & $\mathrm{X}$ & $\mathrm{X}$ & $\mathrm{L}$ & - & A \\
\hline Gouania sp. 1 & $\mathrm{X}$ & & - & - & A \\
\hline Gouania sp. 2 & $\mathrm{X}$ & & $\mathrm{L}$ & - & A \\
\hline \multicolumn{6}{|l|}{ Rubiaceae } \\
\hline Psychotria carthagenensis Jacq. & $\mathrm{x}$ & $\mathrm{x}$ & s & ST & $\mathrm{z}$ \\
\hline \multicolumn{6}{|l|}{ Rutaceae } \\
\hline Balfourodendron riedelianum (Engl.) Engl. & $\mathrm{x}$ & & $\mathrm{T}$ & ST & A \\
\hline Esenbeckia grandiflora Mart. & $\mathrm{X}$ & & $\mathrm{T}$ & ST & $\mathrm{Au}$ \\
\hline Metrodorea nigra A. St.-Hil. & $\mathrm{x}$ & & $\mathrm{T}$ & ST & $\mathrm{Au}$ \\
\hline
\end{tabular}

Ci. Fl., Santa Maria, v. 30, n. 4, p. 1230-1244, out./dez. 2020 
Tabela 1 - Continuação ...

Table 1 - Continuation ...

\begin{tabular}{|c|c|c|c|c|c|}
\hline Families/Species & $\mathbf{F}$ & $\mathbf{R}$ & $\mathbf{L F}$ & EG & DS \\
\hline \multicolumn{6}{|l|}{ Salicaceae } \\
\hline Casearia gossypiosperma Briq. & $\mathrm{x}$ & & $\mathrm{T}$ & ST & A \\
\hline \multicolumn{6}{|l|}{ Sapindaceae } \\
\hline Diatenopteryx sorbifolia Radlk. & $\mathrm{x}$ & & $\mathrm{T}$ & SI & A \\
\hline Sapindaceae & $\mathrm{X}$ & $\mathrm{X}$ & - & - & A \\
\hline Serjania sp. 1 & $\mathrm{X}$ & $\mathrm{X}$ & $\mathrm{L}$ & - & A \\
\hline Serjania sp. 2 & $\mathrm{x}$ & $\mathrm{X}$ & $\mathrm{L}$ & - & A \\
\hline Serjania sp. 3 & $\mathrm{X}$ & & $\mathrm{L}$ & - & A \\
\hline Serjania sp. 4 & $\mathrm{X}$ & & $\mathrm{L}$ & - & A \\
\hline Serjania sp. 6 & $\mathrm{x}$ & & $\mathrm{L}$ & - & A \\
\hline \multicolumn{6}{|l|}{ Solanaceae } \\
\hline Cestrum intermedium Sendtn. & $\mathrm{x}$ & $\mathrm{X}$ & - & - & $\mathrm{Z}$ \\
\hline \multicolumn{6}{|l|}{ Urticaceae } \\
\hline Cecropia glaziovii Snethl.* & $\mathrm{X}$ & $\mathrm{X}$ & $\mathrm{T}$ & SI & $\mathrm{Z}$ \\
\hline Cecropia pachystachya Trécul ${ }^{*}$ & $\mathrm{X}$ & $\mathrm{X}$ & $\mathrm{T}$ & SI & $\mathrm{Z}$ \\
\hline \multicolumn{6}{|l|}{ Verbenaceae } \\
\hline Aloysia virgata (Ruiz \&Pav.) Juss. & & $\mathrm{X}$ & $\mathrm{T}$ & SI & A \\
\hline Citharexylum myrianthum Cham. ${ }^{*}$ & $\mathrm{x}$ & $\mathrm{X}$ & $\mathrm{T}$ & SI & $\mathrm{Z}$ \\
\hline \multicolumn{6}{|l|}{ Unidentified } \\
\hline Morphotype 1 & $\mathrm{x}$ & $\mathrm{X}$ & - & - & - \\
\hline Morphotype 3 & $\mathrm{X}$ & $\mathrm{X}$ & - & - & A \\
\hline Morphotype 6 & $\mathrm{x}$ & & - & - & A \\
\hline Morphotype 9 & $\mathrm{X}$ & $\mathrm{X}$ & - & - & - \\
\hline Morphotype 11 & $\mathrm{X}$ & & - & - & A \\
\hline Morphotype 13 & $\mathrm{x}$ & & - & - & - \\
\hline Morphotype 15 & & $\mathrm{X}$ & - & - & - \\
\hline Morphotype 17 & $\mathrm{X}$ & $\mathrm{X}$ & - & - & - \\
\hline Morphotype 18 & $\mathrm{X}$ & $\mathrm{X}$ & - & - & A \\
\hline Morphotype 22 & $\mathrm{x}$ & & - & - & - \\
\hline Morphotype 23 & $\mathrm{X}$ & & - & - & - \\
\hline Morphotype 26 & $\mathrm{X}$ & $\mathrm{X}$ & - & - & Z \\
\hline Morphotype 35 & & $\mathrm{X}$ & - & - & - \\
\hline Morphotype 36 & $\mathrm{X}$ & & - & - & - \\
\hline Morphotype 40 & $\mathrm{X}$ & & - & - & A \\
\hline
\end{tabular}


Tabela 1 - Conclusão ...

Table 1 - Conclusion ...

\begin{tabular}{|c|c|c|c|c|c|}
\hline Families/Species & $\mathbf{F}$ & $\mathbf{R}$ & $\mathbf{L F}$ & EG & DS \\
\hline Morphotype 41 & $\mathrm{X}$ & $\mathrm{X}$ & - & - & - \\
\hline Morphotype 42 & $\mathrm{X}$ & & - & - & - \\
\hline Morphotype 43 & $\mathrm{X}$ & & - & - & Z \\
\hline Morphotype 44 & $\mathrm{X}$ & & - & - & - \\
\hline Morphotype 48 & $\mathrm{X}$ & & - & - & A \\
\hline Morphotype 49 & & $\mathrm{X}$ & - & - & - \\
\hline Morphotype 50 & & $\mathrm{X}$ & - & - & - \\
\hline Morphotype 51 & $\mathrm{X}$ & $\mathrm{X}$ & - & - & - \\
\hline Morphotype 52 & $\mathrm{X}$ & & - & - & $\mathrm{Z}$ \\
\hline Morphotype 66 & $\mathrm{X}$ & & - & - & A \\
\hline Morphotype 67 & $\mathrm{X}$ & & - & - & A \\
\hline Morphotype 69 & & $\mathrm{x}$ & - & - & - \\
\hline Morphotype 70 & $\mathrm{X}$ & $\mathrm{X}$ & - & - & - \\
\hline Morphotype 71 & $\mathrm{X}$ & & - & - & A \\
\hline Morphotype 77 & & $\mathrm{X}$ & - & - & - \\
\hline Morphotype 81 & $\mathrm{X}$ & & - & - & $\mathrm{Z}$ \\
\hline Morphotype 82 & $\mathrm{X}$ & & - & - & $\mathrm{Z}$ \\
\hline
\end{tabular}

Source: Authors (2020)

Where: $\mathrm{LF}=$ life form $(\mathrm{T}=$ tree, $\mathrm{S}=$ shrub, $\mathrm{L}=$ liana, $\mathrm{H}=$ herb); $\mathrm{EG}=$ ecological group (SI= shade-intolerant species, $\mathrm{ST}=$ shade-tolerant species); $\mathrm{DS}=$ dispersal syndrome (A = anemochory, $\mathrm{Au}=$ autochory, $\mathrm{Z}=$ zoochory); - = non-classified; ${ }^{*}=$ Species planted at the reforestation; $\S=$ alien species.

The indirect ordering of species occurrence data for SF and $\mathrm{R}$ resulted in a stress $=0.19$. The result of PERMANOVA showed significant difference $\left(\mathrm{F}=22.2, \mathrm{df}=1, \mathrm{r}^{2}=0.31, \mathrm{p}<0,001\right)$ between the species composition for the two areas (Figure 3 ).

In the SF, $33 \%$ of species showed up to five propagules (low abundance), being $76 \%$ of the species were exclusive to this area. The proportion of species with low abundance increased in the R (43\%), but only $56 \%$ of the species were exclusive to this area. In all likelihood, these species with low abundance contributed to the low similarity between the areas, as suggested by Rocha, Vieira, and Simon (2016) in a study on regenerating vegetation in degraded areas in the Amazon.

Seed abundance and the species richness did not differ between seasons in the same area (Mann-Whitney test, $\mathrm{p}>0.05$ ). However, the species richness was higher in the SF than $\mathrm{R}$ in both seasons (Mann-Whitney test, $\mathrm{p}<0.05$ ). Abundance of seeds did not differ between areas for both seasons (Mann-Whitney test, $\mathrm{p}>0.05$ ). The composition of species did also not differ between seasons and areas (Permanova $-\mathrm{F}=1.90, \mathrm{df}=1, \mathrm{r}^{2}=0.03, \mathrm{p}=0.07$ ).

The richness and abundance of propagules in the seed rain depends on the fruiting intensity, the successful of propagules dispersal and the density of each species involved. Annual change in the abundance of seeds observed in riparian forest was attributed to a change in the intensity of fruiting or fruiting plant density of some species (ARAUJO et al., 2004). As the seed rain is subject to annual variations in these attributes, it highlights the importance of conducting 
sampling for periods longer than one year.

The matrix surrounding the study areas is agricultural and therefore the SF is the largest source of propagules and dispersers for R. Although the degree of similarity between the fragment and reforestation is relatively low, more than $30 \%$ of species present in the seed rain of $\mathrm{R}$ were probably dispersed from SF. This data becomes more relevant considering the reforestation is recent (10 years).

Figure 3 - Non-metric multidimensional scaling (NMDS) diagram of 1 st and 2nd axes using Bray-Curtis index and a matrix of abundance of propagules for each species in the seed rain of the reforestation $(\Delta)$ and an adjacent seasonal semi-deciduous forest remnant $(\bullet)$ at the northern Paraná, southern Brazil

Figura 3 - Diagrama de escalonamento multidimensional não-métrico (NMDS) de primeiro e de segundo eixos usando índice de Bray-Curtis e matriz de abundância de propágulos para cada espécie na chuva de sementes de um reflorestamento $(\boldsymbol{\Lambda})$ e de remanescente de floresta estacional semidecidual adjacente $(\bullet)$ no norte do Paraná, sul do Brasil

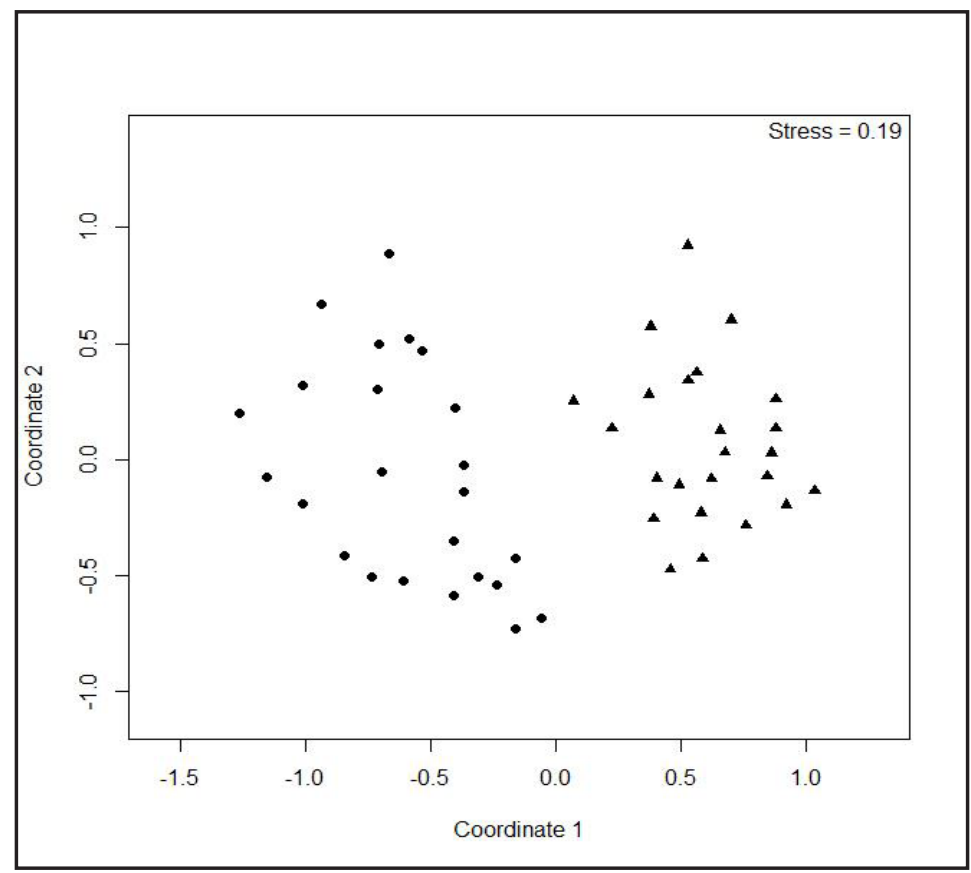

Source: Authors (2020)

Although a few Megathyrsus maximus seeds were registered in the R, this species is abundant in this area, due to the higher incidence of light when compared to the SF. This invasive species is known for arresting the succession and impairing the regeneration of many species (MANTOANI; TOREZAN, 2016).

\section{Life forms}

In the SF, of the 54 species classified as a life form, 45 were classified as trees (83.3\%), one as shrub (1.9\%) and eight as lianas (14.8\%) (Table 1). Higher tree richness in the seed rain was also observed in other studies (e.g. GROMBONE-GUARATINI et al., 2014; REID; HOLL; ZAHAWI, 2015). In the $R$, of the 37 species classified, 31 were classified as tree (83.8\%), one as shrub (2.7\%), four as liana (10.8\%) and, one as herb (2.7\%) (Table 1). Therefore, there is no bias toward any of 
the life forms sampled in the species present in the seed rain in $\mathrm{R}$, when compared to SF. Tree species also contributed the most of the abundance of propagules in both areas. Among the other life form species, only the liana Gouania ulmifolia markedly contributed to the seed rain in both areas.

Regardless of the status conservation, the presence of lianas is common in seasonal semideciduous forest (e.g. COSTA et al., 2011). However, the disturbance, in general, enhances liana abundance in tropical forests (SCHNITZER: BONGERS, 2002). Because of human disturbance, the $\mathrm{SF}$ has a discontinuous canopy and probably, this explains the abundance of lianas in the crown of many trees (personal observation).

\section{Ecological groups}

Of the 45 species classified as the ecological group to the SF, most of the species $(66.7 \%)$ belong to the shade-intolerant group (Table 1). In the R, of the 33 species classified, $88 \%$ belong to shade-intolerant group (Table1). For the $\mathrm{R}$, it was expected that the proportion of shade-intolerant species was greater than the tolerant species, due to the predominance of these species in the cocktail used in planting. However, the result is similar when we disregard the planted species. In addition, shade-tolerant species planted in $\mathrm{R}$ have probably not yet reached reproductive maturity. Similar results were recorded in Costa Rica (ZAMORA; MONTAGNINI, 2007). The shade-intolerant, mostly pioneer species present high seed production and efficient dispersal, which explains the results obtained in this study. Species from early succession are important in the fate of succession in the reforestation because they improve soil quality by producing litter, ameliorating compaction and interacting with soil fauna, thereby facilitating the establishment of later succession species and to hinder the growth of invasive plants like Megathyrsus maximus (CAVALHEIRO; TOREZAN; FADELLI, 2002; AVENDAÑO-YÁÑEZ et al., 2014).

The higher richness of shade-intolerant species in the seed rain of the SF, similar to that observed in other studies (e.g. JESUS et al., 2012; GROMBONE-GUARATINI et al., 2014), may be related to their copious production of small seeds and also to human disturbance, that lead to an increase in the abundance of those plants.

\section{Dispersal syndromes}

We sampled 51 anemochorous species, 34 zoochorous species, 14 autochorous species and 21 species remained without classification. Of the 88 species classified in the SF, 46 were anemochorous, 29 zoochorous and 13 autochorous species. In the R, we recorded 21 zoochorous species, 21 anemochorous species and six autochorous species, among 48 classified species (Table 1). In this site, anemochorous species prevailed (53\%) when we disregard the planted species. The abundance of zoochorous propagules was higher than anemochorous in both areas (KruskalWallis, $\mathrm{p}<0.05)$.

Disregarding the abundance of Ficus eximia in the SF, the seed rain was dominated by anemochorous species in abundance and richness, similar to other seasonal semi-deciduous forest fragments studied (GROMBONE-GUARATINI; RODRIGUES, 2002, CAMPOS et al., 2009; GROMBONE-GUARATINI et al., 2014). The more open canopy and deciduousness in these remnants can favor the establishment of lianas and shade-intolerant trees that generally showed wind dispersal (CAMPOS et al., 2009).

The greater abundance of zoochorous diaspores in $\mathrm{R}$ may reflect availability of food for frugivores, resulting in the attraction of the fragment-resident fauna. This result contrasts with that recorded for 10 years old reforestations (BARBOSA; PIZO, 2006), which showed greater abundance of the anemochorous species. While these species are important for the initial colonization of the area, its dominance for a long time can reflect a slower succession, likely because those species are unattractive for vertebrate dispersers, decreasing the arrival of 
zoochorous diaspores (BARBOSA; PIZO, 2006).

When we compared the seasons, we did not observe a difference in the richness and abundance of propagules belonging to each dispersal syndromes in the SF (Mann-Whitey test, $\mathrm{p}>0.05$ ). In the $\mathrm{R}$, we observed higher richness of autochorous species and higher abundance of anemochorous propagules in the rainy season than the dry season (Mann-Whitney test, $\mathrm{p}<0.05$ ). In a study carried out in seasonal semi-deciduous forest remnant, Grombone-Guaratini and Rodrigues (2002), recorded a greater proportion of the anemochorous propagules during the dry season and early in the rainy season, zoochorous propagules in the rainy season and autochorous in the middle of the dry season. However, in other seasonal semi-deciduous forest remnant, Campos et al. (2009) observed that anemochorous and zoochorous propagules were predominant in the rainy season, but the first occurred early, and the second late in the rainy season, respectively. Perhaps, the lack of clear seasonality in our study region may explain these differences.

Although the propagules size was not measured, in general, the zoochorous propagules sampled were smaller than $0.5 \mathrm{~cm}$, indicating that the large-seeded species, their dispersers or both are rare or absent in the study area. Plants with large seeds are dispersed by animals more susceptible to the effects of fragmentation than those with small seeds (CRAMER; MESQUITA; WILLIAMSON, 2007). Consequently, the fragmentation has little or no effect on the dispersal of plants with small seeds, whereas those with large seeds are strongly affected (CRAMER; MESQUITA; WILLIAMSON, 2007). Species richness of frugivorous birds was lower in both SF and $\mathrm{R}$ than other forest remnants in the region (SANTOS-JUNIOR et al., 2016). Zoochorous largeseeded species usually suffer the lack of appropriate seed dispersers (frugivorous mammals and birds) in disturbed areas (PIZO, 2004).

Although studies in seasonal semi-deciduous forests have recorded that the fruiting species follows a seasonal pattern, tropical forests do not exhibit seasonality so marked as to temperate forests, where the seasonal changes in fruiting cause abrupt changes in the diet of dispersers. In the tropical forest there are periods of the lower food availability, but zoochorous species were sampled all year (JUSTINIANO; FREDERICKSEN, 2000; BIANCHINI et al., 2015), such as observed in this study. This allows the permanence of animals all year in these forests.

\section{Conclusions}

The results indicated that the richness and composition of propagules species differed between SF and R. Richness was lower in the first year for both sites and the SF showed greater abundance of propagules in the first year because of Ficus eximia. Abundance and richness of species propagules did not differ between seasons for the same area. Seed rain of both sites was dominated by tree, shade-intolerant and anemochorous species.

As an important proportion of the $\mathrm{R}$ seed rain comes from non-planted species, and most of this species are also present in the forest fragment seed rain, we suggested that this neighbor forest is a key source of propagules for succession in the restoration site. However, some caveats should be highlighted here. First, the two years of seed rain sampled in the reforestation should be at the higher range of diversity because of the contiguity with the forest fragment. Second, the arrival of seeds does not warrant establishment in the restoration site environment. Finally, the fate of large seeded, vertebrate-dispersed species should be considered in management initiatives.

\section{Acknowledgements}

This study was funded by Conselho Nacional de Desenvolvimento Científico e Tecnológico CNPq (309244/2015-3; grant to JMTD); PELD-CNPq (441540/2016-3) and PELD-Fundação Araucária (work plan 41872.434.40722.27092013, agreement 1020/2013). The authors also thank to CNPq for providing scientific initiation grant to V. F. V., P. C. S. and L. R. B.; Instituto Agronômico do Paraná that provided the climate data; and João Fernando M da Silva for aid in the statistical analysis. 


\section{References}

ALVARES, C. A. et al. Köppen's climate classification map for Brazil. Meteorologische Zeitschrift, Stuttgart, v. 22, n. 6, p.711-728, Dec. 2013.

APG IV. An update of the Angiosperm Phylogeny Group classification for the orders and families of flowering plants. Botanical Journal of the Linnean Society, Oxford, v.181, n. 1, p.1-20, May 2016.

ARAUJO, M. M. et al. Caracterização da chuva de sementes, banco de sementes do solo e banco de plântulas em Floresta Estacional Decidual Ripária, Cachoeira do Sul, RS, Brasil. Scientia Forestalis, Piracicaba, v. 66, p. 128-141, Dez. 2004.

AVENDAÑO-YÁÑEZ, M. L. et al. Is facilitation a promising strategy for cloud forest restoration? Forest Ecology and Management, London, v. 329, p. 328-333, Oct. 2014.

BARBOSA, K. C.; PIZO, M. A. Seed rain and seed limitation in a planted gallery forest in Brazil. Restoration Ecology, London, v. 14, n. 4, p. 504-515, Dec. 2006.

BIANCHINI, E. et al. Phenology of two Ficus species in seasonal semi-deciduous forest in Southern Brazil. Brazilian Journal of Biology, São Carlos, v. 75, n. 4S1, p. S206-S214, Nov. 2015.

CAMPOS, E. P. et al. Chuva de sementes em floresta estacional semidecidual em Viçosa, MG, Brasil. Acta Botanica Brasilica, São Paulo, v. 23, n. 2, p.451-458, Jun. 2009.

CAVAlHEIRO, A. L.; TOREZAN, J. M. D.; FADELLI, L. Recuperação de áreas degradadas: procurando por diversidade e funcionamento dos ecossistemas. In: MEDRI, M. E. et al. (eds.). A bacia do Rio Tibagi. Londrina: Edição dos editores, 2002. p. 213-224.

COLWELL, R. K. EstimateS 9.1.0. Storrs: University of Connecticut, 2013.

COSTA, J. T. et al. Composição florística das espécies vasculares e caráter sucessional da flora arbórea de um fragmento de Floresta Estacional Semidecidual no Sul do Brasil. Revista Brasileira de Botânica, São Paulo, v. 34, n. 3, p. 411-422, Set. 2011.

CRAMER, J. M.; MESQUITA, R. C. G.; WILLIAMSON, G. B. Forest fragmentation differentially affects seed dispersal of large and small-seeded tropical trees. Biological Conservation, London, v. 137, n. 3, p. 415-423, Jul. 2007.

ENDRESS, B. A.; CHINEA, D. Landscape patterns of tropical forest recovery in the republic of Palau. Biotropica, Lawrence, v. 33, n. 4, p. 555-565, Dec. 2001.

FLORA DO BRASIL. Flora do Brasil 2020, em construção. Rio de Janeiro: Jardim Botânico do Rio de Janeiro. Disponível em: http://reflora.jbrj.gov.br. Acesso em: 07 Ago. 2019.

GROMBONE-GUARATINI, M. T.; RODRIGUES, R. R. Seed bank and seed rain in a seasonal semi-deciduous forest in south-eastern Brazil. Journal of Tropical Ecology, Cambridge, v. 18, n. 5, p.759-774, Sep. 2002.

GROMBONE-GUARATINI, M. T. et al. Seed rain in areas with and without bamboo dominance within an urban fragment of the Atlantic Forest. Acta Botanica Brasilica, Feira de Santana, v. 28, n. 1, p.76-85, Mar. 2014.

GUARIGUATA, M. R.; OSTERTAG, R. Neotropical secondary forest succession: changes in structural and functional characteristics. Forest Ecology and Management, London, v. 148, p. 185-206, Jul. 2001.

HAMMER, O.; HARPER, D. A. T.; RYAN, P. D. PAST: Palaeontological Statistics Software Package for education and data analysis. Palaeontologia Electronica, [s.l.], v. 4, n. 1, p. 1-9, Jun. 2001. 
JESUS, F. M. et al. The importance of landscape structure for seed dispersal in rain forest fragments. Journal of Vegetation Science, London, v. 23, n. 6, p. 1126-1136, Dec. 2012.

JUSTINIANO, M. J.; FREDERICKSEN, T. S. Phenology of tree species in Bolivian dry forests. Biotropica, Lawrence, v. 32, n. 2, p. 276-281, Jun. 2000.

MANTOANI, M. C.; TOREZAN, J. M. D. Regeneration response of Brazilian Atlantic Forest woody species to four years of Megathyrsus maximus removal. Forest Ecology and Management, London, v. 359, p. 141-146, Jan. 2016.

MARTINEZ-RAMOS, M.; SOTO-CASTRO, A. Seed rain and advanced in a tropical rain forest. Vegetatio, Heidelberg, v. 107/108, n. 1, p. 299-318, Jun. 1993.

PEREIRA, L. C. S. M.; OLIVEIRA, C. C. C.; TOREZAN, J. M. D. Woody species regeneration in Atlantic Forest restoration sites depends on surrounding landscape. Natureza \& Conservação, [s.l.], v. 11, n. 2, p.138-144, Dec. 2013.

PIZO, M. A. Frugivory and habitat use by fruit-eating birds in a fragmented landscape in southeast Brazil. Ornitologia Neotropical, [s.l.], v. 15, n. 1S, p. 117-126, 2004.

R CORE TEAM. R: a language and environment for statistical computing. Vienna: $R$ Foundation for Statistical Computing, 2014. http://www.R-project.org/

REID, J. L.; HOLL, K. D.; ZAHAWI, R. A. Seed dispersal limitations shift over time in tropical forest restoration. Ecological Application, Washington, v. 25, n. 4, p. 1072-1082, Jun. 2015.

ROCHA, G. P. E.; VIEIRA, D. L. M.; SIMON, M. F. Fast natural regeneration in abandoned pastures in southern Amazonia. Forest Ecology and Management, London, v. 370, p. 93-101, Jun. 2016.

SANTOS-JUNIOR, P. C. A. et al. The importance of restoration areas to conserve bird species in a highly fragmented Atlantic forest landscape. Natureza \& Conservação, [s.l.], v. 14, n. 1, p. 1-7, Jun. 2016

SCHNITZER, A. S.; BONGERS, F. The ecology of lianas and their role in forests. Trends Ecology \& Evolution, London, v. 17, n. 5, p. 223-230, May 2002.

SILVA, F. C.; SOARES-SILVA, L. H. Arboreal flora of the Godoy Forest State Park, Londrina, PR, Brazil. Edinburgh Journal of Botany, Cambridge, v. 57, n. 1, p. 107-120, Mar. 2000.

SUGANUMA, M. S.; DURIGAN, G. Indicators of restoration success in riparian tropical forests using multiple reference ecosystems. Restoration Ecology, London, v. 23, n. 3, p. 238-251, May 2015.

ZAMORA, C. O.; MONTAGNINI, F. Seed rain and seed dispersal agents in pure and mixed plantations of native trees and abandoned pastures at La Selva Biological Station, Costa Rica. Restoration Ecology, London, v. 15, n. 3, p. 453-461, Sep. 2007. 